Forcada N., Macarulla M., Gangolells M.; Casals M. Assessment of construction defects in residential buildings in Spain, Building Research \& Information, .2014, 42(5): 629-640. <doi: 10.1080/09613218.2014.922266>.

Final version available at:

$<$ http://www.tandfonline.com/doi/abs/10.1080/09613218.2014.922266?mobileUi=0 $>$.

\title{
Assessment of construction defects in residential buildings in Spain
}

Nuria Forcada ${ }^{1}$, Marcel Macarulla ${ }^{2}$, Marta Gangolells ${ }^{3}$, Miquel Casals ${ }^{4}$

${ }^{1}$ Professor, Dept. of Construction Engineering, Universitat Politècnica de Catalunya, C/Colom, 11, Ed TR-5, 08222 Terrassa, Barcelona, Spain. (corresponding author). E-mail: nuria.forcada@upc.edu

${ }^{2} \mathrm{PhD}$ student, Dept. of Construction Engineering, Universitat Politècnica de Catalunya, C/Colom, 11, Ed TR-5, 08222 Terrassa, Barcelona, Spain. E-mail: marcel.macarulla@upc.edu

${ }^{3}$ Professor, Dept. of Construction Engineering, Universitat Politècnica de Catalunya, C/Colom, 11, Ed TR-5, 08222 Terrassa, Barcelona, Spain. E-mail: marta.gangoells@upc.edu

${ }^{4}$ Professor, Dept. of Construction Engineering, Universitat Politècnica de Catalunya, C/Colom, 11, Ed TR-5, 08222 Terrassa, Barcelona, Spain. E-mail: miquel.casals@upc.edu

\begin{abstract}
The housing industry is characterized for its repeated building defects causing cost increase and time delay during the construction. In Spain, despite the Ley de Ordenación de la Edificación (Building Regulation Act) which establishes a general framework within which to promote overall building quality, defects during construction in houses remain a pervasive problem. This paper presents the findings from a research project that analysed the location, subcontract, and element of 3647 construction defects derived from two Spanish builders and sixty eight residential developments. The research reveals that the most common defects that arise during construction are problems with the stability of the structure and inappropriate installation of roofs and façades, all technical related items and caused by poor workmanship rather than the quality of the materials or products used. Comparing these results to a previous study carried out in Spain regarding the remaining defects after handing over the building, it can be concluded that during construction the nature of defects is basically technical, and at handover it is aesthetic or technical.
\end{abstract}

Author keywords:

Spain, construction defects, quality, element, location, subcontract 


\section{INTRODUCTION}

Quality management in the residential sector has received considerable attention (Farrington 1987, Forcada et al., 2012, Hall \& Tomkins 2001, Ilozor et al., 2004, Josephson 1999, Josephson et al. 2002, Karim et al. 2006, Love \& Sohal 2003, Mills et al., 2009, Porteous 1992). In fact, numerous studies have been carried out highlighting the factors affecting the quality of housing (e.g., Chong \& Low, 2006, Johnsson, 2009). However, the volume of research specifically related to quality during new-build private housing construction has been limited (e.g., Georgiou et al., 1999, Ilozor et al., 2004, Mills et al., 2009, Sommerville \& McCosh, 2006).

In Spain, the Ley de Ordenación de la Edificación (Building Regulation Act) established a general framework within which to promote overall building quality. The Act establishes the basic requirements to be met by buildings. These requirements cover both the functional and safety aspects of the buildings as well as those referring to habitability (Jefatura del Estado, 1999). Despite the introduction of this act, defects in housing remain common (Forcada et al., 2012).

Within the housing sector, there are two major opportunities for the builder to rectify defective elements: during the construction and prior to the handover of the property when a range of inspections by site management and relevant warranty and guarantee providers should take place. In previous studies, Forcada et al. (2013) analyzed the defects that remain after handing over the building by examining client complaint forms from four Spanish builders' databases. This study concluded that most common defects identified at handover by customers were predominately functional rather than technical in nature. While the legislation focuses on structural stability, any structural defect was identified after handing over the building. In general, these defects included incorrect or missing grouting in tiles, fixtures and fittings in toilets, failure to apply second coats of paint to walls or surface/appearance defects such as floor or wall unevenness, stains, mess, small cracks and marks mainly caused by lack of protection.

Taking into account that previous studies (Bentley, 1981, Bonshor \& Harrison, 1982, Ilozor et al., 2004) identified problems with the stability of the structure as the most important construction defects in housing and no study was carried out in Spain, the research presented in this paper examines the nature of defects during the construction stage and compares it with those defects that remain after handing over the building by identifying their type, elemental characteristics and the subcontract trade where they arose for 68 developments constructed in Spain.

This comparison will provide information about what defects occurred during construction, which were rectified and fixed before handing over the building and which arose at the final stages due to lack of protection or hurry to finish the work. The determination of the typical locations, subcontracts, and elements where defects arose in residential buildings provides invaluable knowledge about those areas where 
builders are likely to make errors, mistakes or deliberately take short-cuts during construction. Understanding the nature of defects and their initiating conditions can enable strategies for their reduction to be developed.

\section{CONSTRUCTION DEFECTS}

Numerous definitions of defects can be found in the normative literature (e.g., Ilozor et al., 2004, Mills et al., 2009). The most comprehensive definition has been provided by Watt (1999) who defined a defect as a "failing or shortcoming in the function, performance, statutory or user requirements of a building, and might manifest itself within the structure, fabric, services or other facilities of the affected building".

Chong \& Low (2005) and Qazweeni \& Daoud (1991) suggested that many building defects are latent in nature and do not appear early in the construction stage. However, other studies found important defects arising during the first stages of the construction process and identified that the problems with the stability of the structure as the most important construction defects in housing (Bentley, 1981, Bonshor \& Harrison, 1982, Ilozor et al., 2004). Illozor et al. (2004) analyzed the causes of defects in new homes in Australia and observed that, if house framing is properly executed, most faults may not arise.

Ahmed and Stephenson (1997) state that many defects are avoidable and are related to design and construction problems. Such problems have been estimated to represent $95 \%$ of all defect items. Although workmanship and incomplete works are also common causes of defects (Georgiou et al., 1999) the lack of skill shown by tradesman was not a major problem but the lack of care shown by the tradesman was a problem (Bentley, 1981). What becomes clear is that the elimination or potential reduction of defect levels will provide a strong financial incentive to improve the construction process (Craig, 2006). To do so, what we need to understand is how these defects occur using real data.

The majority of research investigating defects in housing has been based on observation and surveys. Only few studies such as Georgiou (1999), Illozor et al. (2004), Sommerville et al. (2004), Sommerville \& McCosh (2006), Chong \& Low (2005) and Forcada et al. (2013) were based on real data.

\section{RESEARCH APPROACH}

For the purposes of research reported in this paper the definition of a defect proposed by Watt (1999), as noted above, is adopted. In analyzing construction defects data was classified according to the characteristics of the flat and defect type. Similar approaches have been adopted by a number of authors such as Trotman (1994), Georgiou et al. (1999), Olubodun and Mole (1999), Mills et al. (1999), Chew (2005), Chong and Low (2005, 2006), and Craig et al. (2010), Macarulla et al. (2013 in press). Building characteristics include gross floor area (GFA), number of flats and 
construction cost. Defect characteristics include data about the type of defect (e.g. appearance, stability/movement, etc.), the defect location (e.g. bathroom, terrace) (Karim et al. 2006), the affected building element (e.g. internal wall, window) (Watt, 1999) and the respective subcontract trade (e.g. foundations, coatings). Therefore, the defect classifications proposed by Macarulla et al. (2013, in press) is used as the basis to develop a robust system for this study.

\subsection{Data Collection}

Data was collated from non-conformances forms from two big Spanish builders' databases. Both of them were certified by ISO 9001 and were tracking and analysing non-conformances in a standardized way.

These databases contained information concerning the building and defect characteristics. A total of 3.676 defects from 68 buildings were identified and analysed.

The buildings were constructed between 2007 and 2010. The GFA of the buildings ranged from 3.245 to 48.796 square meters and the number of flats ranged from 24 to 451. Table 1 identifies the main characteristics of the analyzed buildings.

\begin{tabular}{ccccc}
\hline Building & Construction cost & GFA (m2) & Number of flats & $\begin{array}{c}\text { Number of } \\
\text { defects }\end{array}$ \\
\hline 1 & $17.100 .000,00$ & 17.466 & 142 & 149 \\
2 & $11.800 .000,00$ & 12.896 & 104 & 84 \\
3 & $17.299 .000,00$ & 14.253 & 100 & 72 \\
4 & $13.200 .000,00$ & 14.916 & 113 & 48 \\
5 & $7.466 .000,00$ & 11.760 & 80 & 57 \\
6 & $10.379 .000,00$ & 21.151 & 172 & 77 \\
7 & $13.662 .890,00$ & 26.862 & 222 & 115 \\
8 & $23.449 .039,00$ & 22.465 & 135 & 129 \\
9 & $13.401 .303,00$ & 14.766 & 138 & 38 \\
10 & $18.127 .804,00$ & 26.677 & 259 & 33 \\
11 & $19.556 .314,00$ & 25.145 & 235 & 131 \\
12 & $5.996 .021,00$ & 6.270 & 60 & 31 \\
13 & $6.704 .917,00$ & 9.419 & 91 & 87 \\
14 & $9.264 .942,00$ & 11.766 & 106 & 25 \\
15 & $12.000 .000,00$ & 12.120 & 135 & 47 \\
16 & $13.416 .364,00$ & 16.800 & 187 & 3 \\
17 & $16.401 .589,00$ & 32.974 & 234 & 37 \\
18 & $13.476 .275,00$ & 28.634 & 206 & 42 \\
19 & $5.600 .000,00$ & 14.500 & 116 & 15 \\
20 & $19.695 .986,00$ & 41.697 & 369 & 365 \\
21 & $14.227 .000,00$ & 12.740 & 91 & 59
\end{tabular}




\begin{tabular}{|c|c|c|c|c|}
\hline 22 & $8.238 .776,00$ & 10.396 & 92 & 54 \\
\hline 23 & $5.566 .032,00$ & 8.064 & 72 & 134 \\
\hline 24 & $9.000 .000,00$ & 8.879 & 83 & 130 \\
\hline 25 & $15.755 .000,00$ & 13.552 & 176 & 130 \\
\hline 26 & $10.550 .076,00$ & 7.149 & 69 & 108 \\
\hline 27 & $12.182 .339,00$ & 15.205 & 144 & 158 \\
\hline 28 & $4.457 .834,00$ & 7.044 & 68 & 15 \\
\hline 29 & $6.813 .548,00$ & 5.886 & 54 & 44 \\
\hline 30 & $8.835 .035,00$ & 4.970 & 35 & 88 \\
\hline 31 & $9.592 .504,00$ & 11.784 & 61 & 28 \\
\hline 32 & $4.209 .592,00$ & 4.128 & 26 & 13 \\
\hline 33 & $8.411 .949,00$ & 15.300 & 140 & 2 \\
\hline 34 & $5.185 .312,00$ & 5.350 & 53 & 58 \\
\hline 35 & $20.904 .525,00$ & 48.796 & 451 & 24 \\
\hline 36 & $7.420 .000,00$ & 15.300 & 100 & 10 \\
\hline 37 & $4.165 .000,00$ & 8.000 & 55 & 13 \\
\hline 38 & $6.947 .506,00$ & 16.006 & 96 & 39 \\
\hline 39 & $9.803 .266,00$ & 17.135 & 125 & 5 \\
\hline 40 & $2.479 .307,00$ & 3.412 & 30 & 25 \\
\hline 41 & $4.153 .744,00$ & 8.000 & 78 & 9 \\
\hline 42 & $16.128 .611,00$ & 34.946 & 232 & 35 \\
\hline 43 & $5.972 .530,00$ & 10.000 & 128 & 31 \\
\hline 44 & $6.677 .468,00$ & 12.600 & 50 & 12 \\
\hline 45 & $5.279 .039,00$ & 13.702 & 82 & 30 \\
\hline 46 & $8.637 .277,00$ & 21.170 & 152 & 34 \\
\hline 47 & $2.109 .540,00$ & 3.245 & 25 & 37 \\
\hline 48 & $4.516 .948,00$ & 9.056 & 71 & 13 \\
\hline 49 & $5.000 .000,00$ & 8.790 & 65 & 21 \\
\hline 50 & $10.822 .813,00$ & 13.476 & 107 & 50 \\
\hline 51 & $13.597 .164,00$ & 15.696 & 144 & 20 \\
\hline 52 & $4.762 .607,00$ & 5.764 & 43 & 11 \\
\hline 53 & $9.848 .973,00$ & 18.500 & 132 & 75 \\
\hline 54 & $14.504 .375,00$ & 23.283 & 199 & 29 \\
\hline 55 & $5.600 .000,00$ & 9.400 & 81 & 28 \\
\hline 56 & $9.282 .545,00$ & 11.914 & 93 & 44 \\
\hline 57 & $19.509 .998,00$ & 21.000 & 130 & 85 \\
\hline 58 & $4.734 .591,00$ & 6.070 & 55 & 20 \\
\hline 59 & $5.488 .879,00$ & 6.380 & 52 & 92 \\
\hline 60 & $5.488 .879,00$ & 6.380 & 52 & 32 \\
\hline 61 & $19.985 .470,00$ & 15.690 & 128 & 20 \\
\hline 62 & $12.258 .000,00$ & 10.580 & 93 & 5 \\
\hline 63 & $14.000 .000,00$ & 12.748 & 100 & 9 \\
\hline 64 & $7.805 .900,00$ & 11.570 & 100 & 13 \\
\hline
\end{tabular}




\begin{tabular}{ccccc}
65 & $8.324 .077,34$ & 9.086 & 128 & 66 \\
66 & $7.905 .000,00$ & 8.066 & 50 & 8 \\
67 & $11.041 .588,86$ & 9.342 & 128 & 25 \\
68 & $4.493 .416,44$ & 6.946 & 24 & 100 \\
\hline
\end{tabular}

Table 1. Building characteristics

The data collected was analysed using the Statistical Package for the Social Sciences (SPSS) for Windows (Version 17.00). Chi-square test $(\chi 2)$ test was used to determine the relationship between the type of defect that was identified with building element and subcontract trade. In addition, to test the association between variables a Pearson's parametric correlation was computed. This approach made it possible to identify those variables with significant correlations at the $95 \%$ and $99 \%$ confidence intervals.

\section{RESEARCH FINDINGS}

An analysis of the defect data revealed that the most common defects, as noted in Table 2, were: 'inappropriate installation' (24.29\%), 'surface appearance' (14.94\%) and 'affected functionality' (12.04\%).

'Inappropriate installation' includes materials, elements or items not well positioned, or those that do not satisfy project specifications or do not have the characteristics it should have to. Examples of this defect are wrong position of the frames in foundations, not enough length of the starter bars, concrete hoops wrong set up, incorrect installation of beams, errors in the dimensions of installation holes, errors in the crest elevation spot height, etc.

'Surface/appearance' defects included bumps, dips, uneven surfaces, hit, scratches and efflorescence. The majority of the 'surface/appearance' defects detected during construction were honeycombs in concrete elements which were mainly caused by poor workmanship.

'Affected functionality' defects refer to both disabled elements or machines that must be replaced because its functionality is completely affected such as an air conditioning motor that doesn't work and bad operation elements or machines that must be repaired because its functionality is partially affected such as door scrapes on floor.

\begin{tabular}{lcc}
\hline Defect Type & Number of defects & $\%$ \\
\hline Affected functionality & 439 & $12,04 \%$ \\
Detachment & 99 & $2,71 \%$ \\
Flatness and levelness & 195 & $5,35 \%$
\end{tabular}




\begin{tabular}{lcc}
\hline Defect Type & Number of defects & $\%$ \\
\hline Incorrect installation & 886 & $24,29 \%$ \\
Misalignment & 338 & $9,27 \%$ \\
Missing & 425 & $11,65 \%$ \\
Others & 11 & $0,30 \%$ \\
Soiled & 174 & $4,77 \%$ \\
Stability/movement & 13 & $0,36 \%$ \\
Surface appearance & 545 & $14,94 \%$ \\
Tolerance error & 368 & $10,09 \%$ \\
Water problems & 154 & $4,22 \%$ \\
\hline Total & 3647 & $100,00 \%$ \\
\hline
\end{tabular}

Table 2. Defects by type of defect

\subsection{Analysis of Defects by Construction Element}

Tables 3 and 4 present the distribution of defects by construction elements. It can be seen that 'pillars' (13.89\%), 'internal walls' (11.54\%) and 'external walls' (11.27\%) were the elements where most defects arose. Table 5 presents the results of a Chisquare $(\chi 2)$ analysis that sought to determine the independence of the defect type and the respective element. The analysis revealed defect type and element were not independent $(\mathrm{p}<0.05)$.

\begin{tabular}{lcc}
\hline Element & $\begin{array}{c}\text { Number of } \\
\text { defects }\end{array}$ & $\%$ \\
\hline Ceiling & 223 & $6,10 \%$ \\
Concrete wall & 306 & $8,37 \%$ \\
Door & 114 & $3,12 \%$ \\
Exterior woodwork & 27 & $0,74 \%$ \\
External wall & 412 & $11,27 \%$ \\
Floor & 368 & $10,07 \%$ \\
Furniture & 66 & $1,81 \%$ \\
General & 16 & $0,44 \%$ \\
Inernal wall & 422 & $11,54 \%$ \\
Item & 174 & $4,76 \%$ \\
M\&E & 282 & $7,71 \%$ \\
P\&S & 227 & $6,21 \%$ \\
Pillar & 508 & $13,89 \%$ \\
Roof & 93 & $2,54 \%$ \\
Slab & 210 & $5,74 \%$ \\
Stairs & 102 & $2,79 \%$ \\
Window & 106 & $2,90 \%$ \\
\hline Total & 3656 & $100,00 \%$ \\
\hline
\end{tabular}

Table 2. Defects by construction element 
Construction element

\begin{tabular}{|c|c|c|c|c|c|c|c|c|c|c|c|c|c|c|c|c|c|c|}
\hline Type of defect & : & 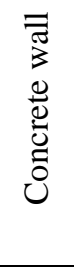 & 苂 & $\begin{array}{l}0 \\
0 \\
0 \\
0 \\
0 \\
0 \\
0 \\
0 \\
0 \\
0 \\
0 \\
0\end{array}$ & 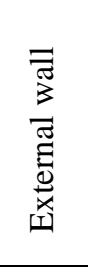 & $\frac{\ddot{\circ}}{\frac{0}{I}}$ & 兽 & $\begin{array}{l}\overline{\widetilde{d}} \\
\overline{0} \\
0\end{array}$ & 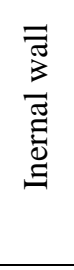 & 苞 & $\frac{\sqrt{2}}{2}$ & $\begin{array}{l}\tilde{z} \\
\tilde{a}\end{array}$ & $\frac{\vec{\Xi}}{\vec{\Xi}}$ & 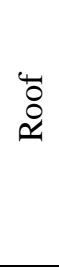 & $\frac{\pi}{\sqrt{n}}$ & 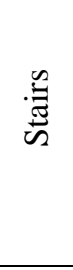 & $\begin{array}{l}3 \\
0 \\
0 \\
0 \\
3\end{array}$ & 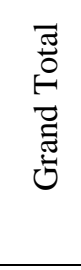 \\
\hline Affected functionality & 32 & 42 & 19 & 4 & 29 & 23 & 2 & 2 & 13 & 38 & 81 & 30 & 77 & 7 & 15 & 16 & 9 & 439 \\
\hline Detachment & 4 & 15 & & & 41 & 10 & & & 5 & 4 & 6 & 2 & 4 & 5 & 1 & 2 & & 99 \\
\hline Flatness and levelness & 10 & 7 & 4 & 2 & 47 & 40 & 2 & & 65 & 7 & 2 & 1 & & 1 & 2 & 1 & 4 & 195 \\
\hline Incorrect installation & 54 & 74 & 43 & 8 & 85 & 72 & 18 & 6 & 85 & 39 & 81 & 48 & 119 & 25 & 51 & 36 & 42 & 886 \\
\hline Misalignment & 7 & 21 & 9 & 1 & 40 & 17 & 3 & & 80 & 16 & 11 & 12 & 91 & 2 & 10 & 6 & 11 & 337 \\
\hline Missing & 28 & 30 & 10 & 8 & 46 & 31 & 12 & 3 & 37 & 28 & 52 & 45 & 34 & 15 & 22 & 8 & 16 & 425 \\
\hline Others & 2 & & & & 1 & 4 & 1 & & & 1 & & 1 & 1 & & & & & 11 \\
\hline Soiled & 14 & 8 & 9 & & 13 & 47 & 7 & 3 & 18 & 15 & 11 & 12 & 6 & 2 & 2 & 2 & 5 & 174 \\
\hline Stability/movement & & 5 & & & 1 & 1 & & & 3 & & & 2 & & & & & 1 & 13 \\
\hline Surface appearance & 47 & 63 & 11 & 3 & 68 & 63 & 17 & 2 & 84 & 16 & 7 & 4 & 95 & 7 & 36 & 17 & 5 & 545 \\
\hline Tolerance error & 13 & 36 & 9 & & 29 & 46 & 4 & & 23 & 5 & 22 & 10 & 80 & 4 & 67 & 14 & 6 & 368 \\
\hline Water problems & 11 & 5 & & 1 & 10 & 11 & & & 7 & 5 & 9 & 60 & & 25 & 3 & & 7 & 154 \\
\hline Total & 223 & 306 & 114 & 27 & 412 & 368 & 66 & 16 & 422 & 174 & 282 & 227 & 508 & 93 & 210 & 102 & 106 & 3656 \\
\hline
\end{tabular}

Table 3. Construction element and type of defect 


\begin{tabular}{lccc}
\hline Value & df & $\begin{array}{c}\text { Asymp. sig (2- } \\
\text { tailed) }\end{array}$ \\
\hline $\begin{array}{l}\text { Pearson chi-square } \\
\text { Likelihood ratio }\end{array}$ & $910.807^{\mathrm{a}}$ & 80 & 0.000 \\
No. of valid cases & 811.345 & 80 & 0.000 \\
\hline a 28.3 had an expected count of $<5$. The minimum expected count was 0.25.
\end{tabular}

Table 5. Chi-square test of independence: Element and defect

From this study, it was revealed that the most common construction defect in whatever element was 'inappropriate installation'. For example, in concrete walls, slabs and pillars, the most common inappropriate installation defects were those sheet pile walls wrongly executed, those planks for prefabricated walls baldly mounted or errors with the concrete or bars dimensioning.

Those 'inappropriate installation' defects in interior and exterior walls were mainly related to setting out the walls and mainly affected the dimensioning of the elements such as the joint between the wall and the floor slab. Other common defects in floor during construction were those inappropriate installation defects such as poor application of grout or poor mixing of the grouting materials. These defects were also detected after handing over the building (Forcada et. al, 2013) meaning that they were not solved or repaired during construction. Problems of inappropriate installation in 'mechanical and electrical systems' (M\&E) were attributed to wrong execution of grilles for ventilation; wrongly executed pipes insulation; air conditioning conducts which were covered by other mechanical element; obstructed shunts, etc. The majority of the affected functionality defects were mainly related to 'M\&E' and 'plumbing and sanitary systems' (P\&S) and to 'pillars' and 'stairs'. Some examples of theses defects are small installation holes, drainpipes covered with concrete, poor insulation thickness, etc. 'M\&E' and 'P\&S' defects were also attributable to missing elements and goods not fitted correctly and/or scratched. The same happens with roofs and windows defects. Most of the missing elements are related to sockets, façade holes for ventilation, pipes insulation, flow meters, valves, etc. This analysis also revealed that 'surface/appearance' defects were mainly detected in ceilings, floors, concrete walls, external and internal walls, pillars, slabs and stairs. Those 'surface/appearance' defects in elements associated with structures were mainly honeycombs. On ceilings and floors 'surface/appearance' defects included bumps, dips, uneven surfaces with missing grout and mastic sealant, hit, scratches and efflorescence. These defects were caused by poor laying practices, such as not using a proper guiding line. Spilled paint and chemicals caused most of the stains during construction. Others were related to plaster work where with uneven walls and ceilings and protruding joints. 
Most of the 'tolerance errors' were mainly in the laying out pillars, slabs and stairs. Although it was revealed that 'water problems' were not much important in construction defects (only $4.22 \%$ ) they were mainly detected in P\&S systems such as pipes leaking, goods not plumbed in or pipes not earth bonded and in the roof. Similarly, 'flatness and levelness' defect was found to be $5.35 \%$ of the total construction defects. However, it was important to notice that this defect was only detected in internal walls.

\subsection{Location of Defects}

Table 6 and 7 presents the distribution of defect location within a dwelling. The findings identify that $72.63 \%$ of defects that arose from the sixty-eight developments were general and exterior areas and floor above ground defects. Table 7 presents the results of a $\chi 2$ analysis that sought to determine the independence of the type of defect and its location of origin. Table 8 revealed defect type and location were not independent $(\mathrm{p}<0.05)$.

\begin{tabular}{lcc}
\hline \multicolumn{1}{c}{ Location } & Number of defects & \\
\hline Common areas & 255 & 6,97 \\
Exterior area & 365 & 9,98 \\
Floor above ground & 305 & 8,34 \\
Floor below ground & 195 & 5,33 \\
Garage & 41 & 1,12 \\
General & 1986 & 54,31 \\
Hall and corridor & 6 & 0,16 \\
Kitchen & 169 & 4,62 \\
Living & 65 & 1,78 \\
Lobby & 37 & 1,01 \\
Main staircasse & 6 & 0,16 \\
Roof & 6 & 0,16 \\
Room & 68 & 1,86 \\
Terrace & 38 & 1,04 \\
Washroom & 115 & 3,14 \\
\hline Total & 3657 & 100,00 \\
\hline
\end{tabular}

Table 6. Defects by location 
Location

\begin{tabular}{|c|c|c|c|c|c|c|c|c|c|c|c|c|c|c|c|c|}
\hline Type of defect & 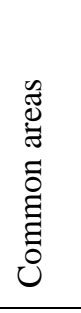 & 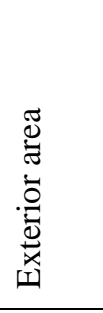 & 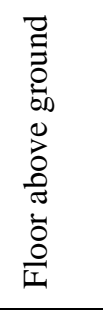 & 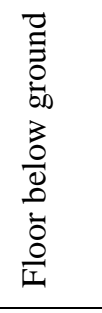 & $\begin{array}{l}\text { 品 } \\
\mathbb{E} \\
\mathbb{J}\end{array}$ & $\begin{array}{l}\overline{\widetilde{J}} \\
\overline{0} \\
\overline{0}\end{array}$ & 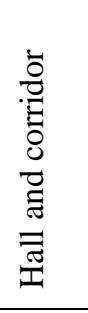 & 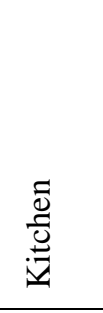 & : & $\begin{array}{l}\overrightarrow{0} \\
\stackrel{0}{0} \\
\end{array}$ & 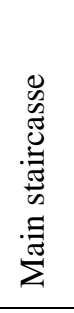 & $\begin{array}{l}\text { पे } \\
\stackrel{0}{8}\end{array}$ & $\begin{array}{l}\tilde{8} \\
\stackrel{0}{0} \\
\end{array}$ & $\underset{\mathscr{E}}{\mathscr{E}}$ & 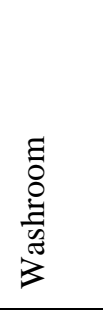 & $\begin{array}{l}\bar{\pi} \\
\stackrel{0}{0} \\
\overrightarrow{0} \\
\tilde{\pi}\end{array}$ \\
\hline Affected functionality & 31 & 29 & 31 & 23 & 4 & 271 & 1 & 17 & 6 & 3 & 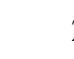 & & 3 & 6 & 12 & 439 \\
\hline Detachment & 7 & 18 & 8 & 5 & 1 & 57 & & 1 & & & & 1 & 1 & & & 99 \\
\hline Flatness and levelness & 14 & 21 & 15 & 13 & 2 & 99 & & 6 & 2 & 1 & & 3 & 13 & 3 & 3 & 195 \\
\hline Incorrect installation & 79 & 83 & 115 & 44 & 10 & 419 & 2 & 52 & 13 & 11 & & 1 & 13 & 7 & 36 & 886 \\
\hline Misalignment & 13 & 32 & 31 & 23 & 1 & 208 & & 7 & 8 & 1 & & & 3 & & 11 & 338 \\
\hline Missing & 26 & 44 & 20 & 17 & 5 & 236 & & 30 & 14 & 8 & & & 9 & 5 & 11 & 425 \\
\hline Others & 6 & & & 1 & & 3 & & & & & & & 1 & & & 11 \\
\hline Soiled & 14 & 28 & 13 & 7 & 1 & 71 & & 12 & 4 & 5 & & & 5 & 1 & 13 & 174 \\
\hline Stability/movement & & 3 & 5 & 1 & & 4 & & & & & & & & & & 13 \\
\hline Surface appearance & 34 & 50 & 44 & 36 & 8 & 306 & 2 & 24 & 14 & 3 & & & 9 & 5 & 9 & 545 \\
\hline Tolerance error & 22 & 31 & 15 & 17 & 8 & 239 & & 13 & 1 & 3 & 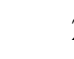 & & 1 & 8 & 8 & 368 \\
\hline Water problems & 8 & 24 & 6 & 8 & 1 & 68 & 1 & 7 & 3 & 2 & & 1 & 10 & 3 & 12 & 154 \\
\hline Grand Total & 254 & 363 & 303 & 195 & 41 & 1981 & 6 & 169 & 65 & 37 & 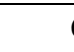 & 6 & 68 & 38 & 115 & 3647 \\
\hline
\end{tabular}

Table 7. Location and type of defect 


\begin{tabular}{lccc}
\hline & Value & df & $\begin{array}{c}\text { Asymp. sig (2- } \\
\text { tailed) }\end{array}$ \\
\hline Pearson chi-square & $385.819^{\mathrm{b}}$ & 80 & 0.000 \\
Likelihood ratio & 369.570 & 80 & 0.000 \\
No. of valid cases & 2351 & & \\
a. 26.3 had an expected count of $<$ 5. The minimum expected count was 0.48.
\end{tabular}

Table 8. Chi-square test of independence: Location and type of defect

The main areas where most defects were identified were 'general areas' (54.31\%). These defects are those that cannot be attributed to a specific location because they are concerned with the whole functioning of the building. General category refers basically to general installations, roof, façades, foundation and structures. As an important amount of work during construction is related to the building envelope it seems normal that a big quantity of defects were attributable to these areas.

On the other hand, when analysing the defects remaining after handing over the building, general defects where only the $6.4 \%$. This contrast is mainly due to the nature of data analysed. In this study, data was obtained from the non-conformances list of several contractors while for the study of the post-handover defects data was obtained from the clients' complaints a few days or weeks after entering into the building (Forcada et al. 2013). From one side, clients and contractors normally have different quality standards and perceptions and from the other side, general and structural defects are normally fixed before handing over the building to assure technical quality.

Regarding foundations and structures, taking into account that these elements are the most important processes during the construction both the number of defects and the impact in terms of cost and time of these defects are highly important.

Analyzing 'exterior' areas and 'floor above and below ground' areas, 'inappropriate installation' was the most common defect although 'surface/appearance' defects were also common.

In the kitchen and living, 'incorrect installation', 'missing' and 'surface/appearance' were those most common defects during construction. While in the washroom, defects were attributed to 'incorrect installation' and 'water problems'.

\subsection{Analysis of defects by Subcontract Trade}

Tables 9 and 10 identify the main subcontract trades where defects arose. 'Structures' (29.01\%), 'partitions and closures' (21.38\%), 'installations' (18.05\%) 
and 'furniture and devices' $(10.12 \%)$ were identified as being problematic trades. Table 11 presents the results of a $\chi^{2}$ analysis that sought to determine the independence of the type of defect and the respective subcontract trade. It was revealed that the defect type and subcontract trade were not independent $(p<0.05)$.

\begin{tabular}{lcc}
\hline \multicolumn{1}{c}{ Subcontract } & $\begin{array}{c}\text { Number of } \\
\text { defects }\end{array}$ & \\
\hline Ceilings & 5 & 0,14 \\
Coatings & 289 & 7,90 \\
Door and window closures & 100 & 2,73 \\
Earthworks & 34 & 0,93 \\
Foundations & 109 & 2,98 \\
furniture and devices & 370 & 10,12 \\
Impermeable membranes & 40 & 1,09 \\
installations & 660 & 18,05 \\
Insulations & 15 & 0,41 \\
Partitions and closures & 782 & 21,38 \\
Pavements & 181 & 4,95 \\
Roofs & 11 & 0,30 \\
Structures & 1061 & 29,01 \\
\hline Total & 3657 & 100,00 \\
\hline
\end{tabular}

Table 9. Defects by subcontract type 
Subcontract $(\%)$

\begin{tabular}{|c|c|c|c|c|c|c|c|c|c|c|c|c|c|c|}
\hline Type of defect & 点 & 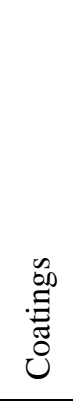 & 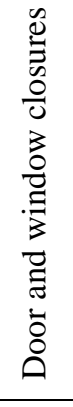 & 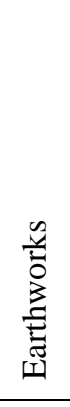 & 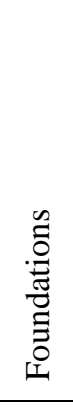 & 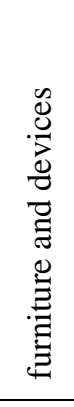 & 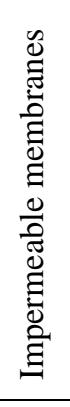 & 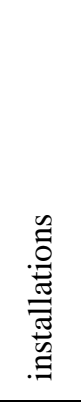 & 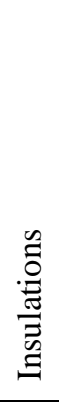 & 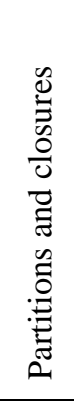 & 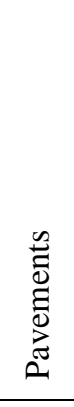 & $\begin{array}{l}\stackrel{n}{0} \\
\stackrel{0}{2}\end{array}$ & $\begin{array}{l}\stackrel{\mathscr{0}}{0} \\
\stackrel{\Xi}{0} \\
\stackrel{E}{E}\end{array}$ & 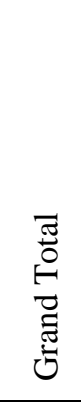 \\
\hline Affected functionality & & 8 & 14 & 3 & 14 & 65 & 1 & 126 & & 47 & 6 & & 155 & 439 \\
\hline Detachment & & 8 & & 4 & 2 & 5 & & 10 & & 50 & 5 & 5 & 10 & 99 \\
\hline Flatness and levelness & & 36 & 7 & & 3 & 16 & & 6 & & 82 & 25 & & 20 & 195 \\
\hline Incorrect installation & 3 & 70 & 37 & & 25 & 117 & 2 & 181 & 3 & 163 & 33 & 2 & 250 & 886 \\
\hline Misalignment & & 5 & 8 & 3 & 10 & 31 & & 38 & & 120 & 4 & 1 & 118 & 338 \\
\hline Missing & & 36 & 12 & 2 & 16 & 50 & 5 & 117 & 4 & 72 & 8 & 2 & 101 & 425 \\
\hline Others & & 1 & & & 2 & & & 1 & & 2 & 2 & & 3 & 11 \\
\hline Soiled & & 21 & 9 & 11 & 3 & 20 & 5 & 34 & 1 & 23 & 31 & 1 & 15 & 174 \\
\hline Stability/movement & & & & 1 & 1 & & & 2 & & 2 & & & 7 & 13 \\
\hline Surface appearance & 2 & 86 & 10 & 3 & 9 & 39 & 2 & 20 & & 145 & 45 & & 184 & 545 \\
\hline Tolerance error & & 16 & 2 & 6 & 21 & 23 & 1 & 46 & & 55 & 12 & & 186 & 368 \\
\hline Water problems & & 1 & 1 & 1 & 2 & 3 & 24 & 79 & 7 & 19 & 9 & & 8 & 154 \\
\hline Grand Total & 5 & 288 & 100 & 34 & 108 & 369 & 40 & 660 & 15 & 780 & 180 & 11 & 1057 & 3647 \\
\hline
\end{tabular}

Table 10. Subcontract and type of defect 


\begin{tabular}{lccr}
\hline & Value & df & $\begin{array}{c}\text { Asymp. sig (2- } \\
\text { tailed) }\end{array}$ \\
\hline Pearson chi-square & $1501.875^{\mathrm{c}}$ & 56 & .000 \\
Likelihood ratio & 1135.072 & 56 & .000 \\
No. of valid cases & 2351 & & \\
\hline c. 23.6 had an expected count $<$ 5. The minimum expected count was 0.19.
\end{tabular}

Table 11. Chi-square test: Subcontract trade and defect

Defects in structures were the most important. However, they were not attributable to 'stability and movement' problems. They were mainly attributable to 'inappropriate installation', 'tolerance error's, 'surface/appearance' and 'affected functionality' defects and 'missing items or tasks'.

Few defects were detected in ceilings, roofs and insulations. 'Partitions and closures subcontract trade' defects were also very important and were caused by 'inappropriate installation', 'surface/appearance', 'misalignment' and 'flatness and levelness' defects. 'Installations defects' were mainly caused by 'affected functionality' defects, 'incorrect installation' of elements, 'missing items or tasks' and 'water problems'. 'Door and window subcontract trade' defects were mainly attributable to 'inappropriate installation'. 'Foundations subcontract trade' was mainly derived from 'inappropriate installation' problems and 'tolerance errors'. 'Furniture and devices subcontract trade' defects were mainly derived from 'inappropriate installation' problems, 'affected functionality' and 'missing items or tasks'.

In summary the analysis demonstrated that defects occurred because of: 'inappropriate installation' of structural elements such as bars, dimensioning of construction elements, joints between wall and the floor slab, poor application of grouting materials in floor; 'surface appearance' in structures such as honeycombs or on ceilings and floors including bumps, dips, uneven surfaces with missing grout and mastic sealant; and 'affected functionality' mainly related to M\&E and P\&S systems such as drainpipes covered with concrete.

\section{DISCUSSION}

Building regulations in Spain such as Código Técnico de la Edificación (Ministerio de Vivienda 2006) (Technical Building Code) are oriented to comply the Ley de Ordenación de la Edificación (LOE) (Jefatura del Estado, 1999) (Building Regulation Act) regarding to functional, habitability and safety aspects.

The LOE also introduces different levels of quality warranties depending on the defects liability period (DLP) and the nature of the defect. During the first ten years the contractor is responsible for addressing the structural defects. For those construction and installation defects that may result in habitability problem the liability period is two years and finally within the first twelve months, the contractor is responsible for 
addressing minor omissions and defects that may have occurred prior to handover (Jefatura del Estado, 1999).

Therefore, contractors focus their quality control in those structural defects that can cause major consequences during the DLP. Noteworthy, although defects appear during the construction stage, important defects are mainly reduced and/or eliminated prior to handover and during the inspection.

Ahmed and Stephenson (1997) revealed that more than $76 \%$ of defects are identified after practical completion (handover of the building or new home) has been awarded. However, noteworthy the defects identified after handing over the building are different from those detected during construction.

Other regulations in Spain such as the Ley reguladora de la subcontratación en el Sector de la Construcción (Jefatura del Estado, 2006) (Subcontracting law) and the Registro de Empresas Acreditadas (2008) (Registry of Accredited Companies) aim to ensure the quality of the work produced by subcontractors. However, the compliance on these regulations does not ensure that a quality control and assurance procedures are put into place because both of them are only oriented to safety and health assurance.

Regarding the quality of construction products, The Construction Products Regulation 305/2011 (European Parliament, 2011) laid down harmonised conditions for the marketing of construction products and established the requirements for the European Conformity (CE) mark in construction products. The CE mark is a mandatory conformity marking for products sold in the European Economic Area (EEA) and enables the free movement of products within the European market. It indicates a product's compliance for the seven basic requirements of construction works: 1. Mechanical resistance and stability, 2. Safety in case of fire, 3. Hygiene, health and environment, 4. Safety and accessibility in use, 5. Protection against noise, 6. Energy economy and heat retention, 7. Sustainable use of natural resources. Moreover, 50.000 construction products in Spain are certified by the N-Aenor voluntary mark (Aenor, 2013) which aims to provide added value covering new characteristics not dealt with in the standard or a higher level of performance assessment. Therefore, the low quantity of defects related to the quality of materials resulting from this analysis confirm that these compulsory and voluntary regulations have improved the construction marked and avoided defects in materials to be generated.

On the other hand, the majority of defects detected during execution were mainly caused by poor workmanship which is the main problem in the Spanish building industry. In the housing industry contractors operate by subcontracting most of the construction work to specialty trade contractors. Indeed, as much as $90 \%$ of the construction work is performed by different trade contractors, whereas the main contractor tends to focus on management and coordination (Karim et al., 2006). The 'multilayer chain subcontracting system', which is widely used in the construction industry, encourages improper work practices by subcontractors and involves long chains of command, thereby contributing to poor quality performance, communication, and coordination (Tam et al., 2011). Further complications arise because most subcontractors involved in housing construction in Spain are small (Asociación de 
empresas constructoras de ámbito nacional, 2011). Emphasis on quality supervision of subcontract trades during execution and assurance of skills of subcontractor trades is critical to ensure defects are reduced (Forcada et al., 2012, 2013, Love et al., 2010, Mills et al., 2009).

Another way to reduce and/or eliminate these defects is to ensure that quality controls and inspections are implemented during design (AECCTI, 1993, Chong \& Low, 2005, Georgiou et al., 1999, Mills et al., 2009). Quality design regulations and forms of work supervision and compliance to see that existing regulations are complied with exist in Spain. Although no design audits or checks are compulsory in residential buildings in Spain, the majority of design companies have a quality management system, such as ISO 9001, implemented and therefore, they carry out design checks.

Other appropriate quality regulations and therefore forms of quality supervision should be implemented with the aim to improve the quality of the work being performed. Similar to training employees about health and safety, education programs on quality related to building procedures and quality management for workers and contractors would improve the quality of the works and therefore reduce construction defects. Training and education programmes should include feedback from workers, trade partners and customers. Workers should be actively encouraged to participate in all quality initiatives and understand how tools and methodologies can be used to attain a 'zero defects' in the residential sector. Striving toward the goal of 'zero defects' will bring to fruition a plethora of tangible benefits which include repeat business, increased sales and profits, and lead to employee and subcontractor satisfaction (Leonard and Taggart, 2010).

Moreover, compulsory quality certification and occupational licensing of subcontract trades should be put in place to ensure that execution defects are reduced (Love et al., 2010).

\section{CONCLUSIONS}

While defects detected during the construction of residential buildings in Spain are mainly addressed prior to handover, rework caused by these defects is an inconvenient and contribute to time and cost increase.

The prevention and possible eradication of defects and an improvement in the overall construction process is possible through the implementation of a quality management system although a major issue within the construction industry is its difficulty to become quality focused.

Time and financial restrictions placed upon contractors and sub-contractors are a major contributory factor to poor quality and therefore defects has become an accepted part of human nature. Quality should be undertaken in parallel with construction activities and the emphasis should be to get it right first time rather than wait until the end of the construction project before tackling those defects arisen during construction. 
From the analysis of sixty eight residential developments the most common defects identified during execution were 'inappropriate installation', 'surface/appearance' and 'affected functionality'.

'Inappropriate installation' includes materials, elements or items not well positioned, mainly in foundations and structures. Typical 'surface/appearance' defects detected during construction include honeycombs in concrete elements mainly caused by poor workmanship. 'Affected functionality' defects were mainly related to M\&E and P\&S systems and to pillars and stairs. Some examples of theses defects are small installation holes, drainpipes covered with concrete, poor insulation thickness, etc.

Comparing the results of this study with those obtained from the analysis of posthandover defects (Forcada, et al., 2013) it can be concluded that although many defects during construction are similar to those detected at handover stage they are different in nature. For example the percentage of 'inappropriate installation' defects during construction $(24.29 \%)$ and at handover $(16.00 \%)$ were relatively similar. However, those defects during construction were mainly wrong position of the frames in foundations, not enough length of the starter bars, concrete hoops wrong set up, incorrect installation of beams, errors in the dimensions of installation holes, errors in the crest elevation spot height, etc. While at post-handover those defects were mainly related to incorrect installation of items such as toilets, TV sockets, radiators, general purpose outlets and were minor in nature.

'Surface/appearance' defects during construction (15,95\%) are similar to those detected during post-handover $(19,95 \%)$, However, the majority of the 'surface/appearance' defects detected during construction are honeycombs in concrete elements which are mainly caused by poor workmanship while at post-handover these defects include bumps, dips, uneven surfaces, hits and scratches on finished unprotected surfaces. In fact, during construction the natures of defects is basically technical, and at handover the nature of the defects are aesthetic or technical.

The determination of the typical locations, subcontracts, and elements where defects arose in residential buildings provided invaluable knowledge about those areas where builders are likely to make errors, mistakes or deliberately take short-cuts during construction.

The analysis revealed that the majority of defects during execution are located in 'general areas' (roof, façades, foundations, structures and installations) which cannot be attributed to a specific flat because they are concerned with the whole functioning of the building. In Spain, quality control during execution exists and focuses on structural problems including foundations, structures, roof and façades as they are the most important and expensive to rectify. However, although they are fixed before handing over the building and typical end users won't complaint about these defects because they normally focus on aesthetic defects which appear during the final stages, they impact on the performance of the building and the efficiency and efficacy of the contractor's business. 
The majority of defects detected during the execution stage are related to the functionality or the installation caused by poor workmanship, not to the materials or products used. In fact, internal and external quality control of materials exist in Spain and results in a high quality of materials.

However, appropriate quality regulations to verify the execution process should be implemented with the aim to improve the quality of the work being performed. Similar to training employees about health and safety, education programs on quality related to building procedures and quality management for workers and contractors would improve the quality of the works and therefore reduce construction defects. Compulsory quality certification and occupational licensing of subcontract trades should be put in place to ensure that execution defects are reduced.

Future research will focus on determining the causes and the costs of defects, which will enable preventive measures to be identified, as well as demonstrate to builders and subcontractors the impact of re-doing defective work on their overall profitability.

Other future research will be to analyze those latent defects in housing and compare them with those construction defects defining the cause and/or relationship between both of them.

\section{REFERENCES}

Asociación de Empresas Constructoras de ámbito nacional - Seopan. (2011). Informe económico (2011). http://www.seopan.es/.

Ahmed, Z. \& Stephenson, P. (1997, December). Intelligent systems approach for predicting defects in housing construction, IASTED International Conference on Intelligent Information Systems, Bahamas.

Asociación Española de Normalización y Certificación -Aenor-. (2013). http://www.aenor.es/.

Bentley, M.J.C. (1981). Quality control on building sites. Building Research Establishment. Watford.

Bonshor, R.B., \& Harrsion, H.W. (1982). Traditional housing: a BRE study of quality. Building Research Establishment, Watford.

Chew, M.Y.L. (2005). Defect analysis in wet areas of buildings. Construction Building Materials. 19(3), 165-173.

Chong, W.K., \& Low, S.P. (2005). Assessment of Defects at Construction and Occupancy Stages. Journal of Performance of Constructed Facilities, 19(4), 283-289.

Chong, W.K., \& Low, S.P. (2006). Latent Building Defects: Causes and Design Strategies to Prevent Them. Journal of Performance of Constructed Facilities. 20(3), 213-221.

Craig, N. (2006). The prevailing trends of defects in new homes in the UK (doctoral dissertation). Glasgow Caledonian University, Glasgow.

Craig, N., Sommerville, J., \& Auchterlounie, T. (2010, September). Customer satisfaction and snagging in the UK private house building sector. 26th Annual ARCOM Conference. Leeds, UK.

European Parliament. (2011). Harmonized conditions for the marketing of construction products $(305 / 2011)$. 
Farrington, J.L. (1987). A methodology to identify and categorise costs of quality deviations in design and quality, (doctoral dissertation). Clemson University, United States of America.

Forcada, N., Macarulla, M., Fuertes, A., Casals, M., Gangolells, M., \& Roca, X. (2012). Influence of Building Type on Post-Handover Defects in Housing. Journal of Performance of Constructed Facilities. 26(4), 433-440.

Forcada, N., Macarulla, M., \& Love, P.E.D. (2013). Assessment of Residential Defects at Post-Handover. Journal of Construction Engineering and Management. 139(4), 372-378.

Georgiou, J., Love, P. E. D., \& Smith, J. (1999). A comparison of defects in houses constructed by owners and registered builders in the Australian State of Victoria. Structural Survey. 17(3), 160-169.

Hall, M., \& Tomkins, C. (2001). A cost of quality analysis of a building project: Towards a complete methodology for design and build. Construction Management and Economics. 19 (7), 727-740.

Ilozor, B. D., Okoroh, M. I., Egbu, C. E., \& Archicentre. (2004). Understanding residential house defects in Australia from the State of Victoria. Building and Environment. 39(3), 327-337.

Jefatura del Estado. (1999). LOE. Ley de Ordenación de la Edificación. 38/1999.

Jefatura del Estado. (2006). Ley reguladora de la subcontratación en el Sector de la Construcción. 32/2006.

Johnsson, H. (2009). Defects in offsite construction: Timber module prefabrication. Construction Management and Economics. 27(7), 667-681.

Josephson, P.E., \& Hammurlaund, Y. (1999). The causes and costs of defects in construction: a study of seven building projects. Automation in Construction. 8(6), 681687.

Josephson, P.E. Larsson, B., \& Li, H. (2002). Illustrative benchmarking rework and rework costs in Swedish construction industry. Journal of Management in Engineering, 18(2) 76-83.

Karim, K., Marosszeky, M., \& Davis, S. (2006). Managing subcontractor supply chain for quality in construction. Engineering, Construction and Architectural Management. 13(1), 27-42.

Leonard, D., \& Taggart. J. (2010). Quality Management and High Performance Home Building: A Case Study of Veridian Homes. The Economics of Quality, MultiYear Advanced Residential Building Systems Research. Final Report of Quality Assurance Activities for New Homes, Maryland, 3-25.

Love, P.E.D., \& Sohal, A.S. (2003). Capturing rework costs in projects. Managerial Auditing Journal. 18(4), 329-339.

Love, P.E.D., Davis, P.R., \& Worrall, D. (2010). Occupational licensing of building trades. Journal of Professional Issues in Engineering and Education, 136(4), 215-223.

Macarulla, M., Forcada, N., Casals, M., Gangolells, M., Fuertes, A. \& Roca, X. (2013). Standardizing housing defects: classification, validation and benefits. Journal of Construction Engineering and Management, doi: 10.1061/(ASCE)CO.19437862.0000669

Mills, A. Love, P.E.D., \& Williams, P. (2009). Defect costs in residential construction. Journal of Construction Engineering and Management. 135(1), 12-16.

Ministerio de Vivienda. (2006). Código Técnico de la Edificación. 314/2006. 
Olubodun, F., \& Mole, T. (1999). Evaluation of defect influencing factors in public housing in the UK. Structural Survey, 17(3), 170-178.

Porteous, W.A. (1992). Classifying building failure by cause. Building Research and Information. 20(6), 350-356.

Qazweeni, J.A., \& Daoud, O.K. (1991). Concrete deterioration in a 20-year-old structure in Kuwait. Cement and Concrete Research. 21, 1155-1164.

Registro de Empresas Acreditadas. (2008). http://rea.mtin.gob.es/rea/.

Sommerville, J., \& McCosh, J. (2006). Defects in new homes: an analysis of data on 1696 new UK houses. Structural Survey 24(1), 6-21.

Sommerville, J., Craig, N., \& Bowden, S. (2004). The Standardisation of Construction Snagging. Journal of Structural Survey. 22(5) 251-258.

Tam, V.W.Y., Shen, L.Y., \& Kong, J.S.Y. (2011). Impacts of multi-layer chain subcontracting on project management performance. International Journal of Project Management. 29(1), 108-116.

Trotman, P. (1994, September). An Examination of the BRE Advisory Service Database Compiled from Property Inspections. International Symposium on Dealing with Defects in Building. Varena, Italy.

Watt, D. S. (1999). Building pathology: principles \& practice. UK. 